\title{
Estimation of Seepage Loss in Irrigation Canals of Tendaho Sugar Estate, Ethiopia
}

\section{Eshetu BD ${ }^{1 *}$ and Alamirew $\mathrm{T}^{2}$}

${ }^{1}$ Ethiopian Sugar Corporation, Research and Development Center, Wonji, Ethiopia

${ }^{2}$ Water and Land Resource Center, Addis Ababa University, Addis Ababa, Ethiopia

\begin{abstract}
Open canals are the common method used to convey water for irrigation in Ethiopian sugar estate, however, little or no attention is given to the evaluation of conveyance systems. Consequently, many of the existing conveyance systems are deteriorating in their physical structures, operation and management. Due to this the current study was conducted to quantify the amount of seepage loss through lined and unlined irrigation canals of Tendaho sugar estate. Seepage losses were determined by inflow-out flow method for primary, secondary, and tertiary canals, while water velocity was determined using a current-meter. The average seepage losses were resulted in $0.55 \%$ per $100 \mathrm{~m}(0.0126$ $\left.\mathrm{lit} / \mathrm{s} / \mathrm{m}^{2}\right)$ and $0.84 \%$ per $100 \mathrm{~m}\left(0.0180 \mathrm{lit} / \mathrm{s} / \mathrm{m}^{2}\right)$ for lined and unlined primary canals whereas, $3.65 \%$ per $100 \mathrm{~m}(0.0391$ $\left.\mathrm{lit} / \mathrm{s} / \mathrm{m}^{2}\right)$ and $4.27 \%$ per $100 \mathrm{~m}\left(0.0248 \mathrm{lit} / \mathrm{s} / \mathrm{m}^{2}\right)$ were obtained for secondary and tertiary canals, respectively. In the result, primary canal seepage loss was higher in unlined than in lined by $0.0054 \mathrm{lit} / \mathrm{s} / \mathrm{m}^{2}$ of wetted area of the canal. The result reveals that high seepage loss for both lined and unlined canals may be attributed through damage of geomembrane lining and poor maintenance of earthen canals. To minimize excess seepage and improve the conveyance system, overall maintenance and repair of canals should be done in the Estate.
\end{abstract}

Keywords: Irrigation canals; Seepage loss; Tendaho sugar estate

\section{Introduction}

Open canal continues to be the major irrigation water conveyance system from dam or reservoirs in Ethiopian. During transportation, water that seeps through the bed, sides, and evaporation from the surface of a canal could be a loss to the demand. The seepage losses from irrigation canals constitute a substantial percentage of the usable water [1]. On the other hand, seepage losses not only lead to depletion of fresh water resources but also cause water logging, salinization and ground water contamination in the nearby areas of the canal system [2]. Therefore, computation of the seepage losses from canals is an important aspect for sustainable management of land and water resources.

Canals are often lined to reduce the seepage. But canal lining deteriorates with time and hence, significant seepage losses continue to occur from a lined canal. Providing perfect lining can prevent seepage loss from canals, but cracks and damage in lining develop due to several reasons and performance of canal lining deteriorates with time [3]. Seepage losses from earthen irrigation canals depend on a number of factors and vary from 30 to 50 percent of the discharge available at the head of an irrigation system [1,4]. The study conducted on earthen canals at Wonji-Showa Sugar Estate showed that mean seepage loss was 2,099.33 lit/day $/ \mathrm{m}^{2}$ [5]. In addition, the result obtained on Tendaho Sugar Estate also showed that the mean conveyance efficiency of tertiary canal was about $59.6 \%$ per $400 \mathrm{~m}$ canal length, indicating high amount of water losses [6].

Currently, there is ongoing 50,000 hectare large-scale irrigation development in the downstream reach Awash River basin, called 'Tendaho Sugar Estate'. The cane cultivation field is getting its water supply from Tendaho Dam that has a capacity of holding more than 1.8 billion cubic meter water, and the main canal has $72 \mathrm{~km}$ length and $78 \mathrm{~m}^{3} / \mathrm{s}$ full supply discharge capacity. The discharge capacity and length of primary and secondary canals depend on the irrigation areas. The main and most of the primary canals are lined with geo-membrane while the secondary and tertiary canals are earthen (unlined) open canal system.

However, poor operation and damage of irrigation canal system have been observed in the Tandaho Sugar Estate. Hence, water logging in nearby the canal and water shortage for downsteam field are commonly observed problems due to high seepage losses. In addition, the magnitude and severity of the problem has not been quantified through a systematically seepage loss investigation for all canal levels in the system. Therefore, this study was carried out to quantify seepage losses for lined and unlined irrigation canals of the Sugar Estate.

\section{Specific objectives}

1. To investigate seepage loss from primary, secondary and tertiary canals in Tandaho Sugar Estate and

2. To compare seepage loss through lined and unlined primary canals.

\section{Materials and Methods \\ Description of the study area}

The study was conducted in Tendaho Sugar Estate which is located between $11^{\circ} 30^{\prime}$ to $11^{\circ} 50^{\prime}$ North Latitude and $40^{\circ} 45^{\prime}$ to $41^{\circ} 03^{\prime}$ East Longitude, at about $610 \mathrm{~km}$ East of Addis Ababa with an altitude of $350 \mathrm{~m}$ a.s.l. (Figure 1). The entire command area lies in deltaic alluvial plains with gentle slope ranging from 0.05 to $0.5 \mathrm{~m}$ per kilometer. The elevation of command area varies from $365 \mathrm{~m}$ at dam site to $340 \mathrm{~m}$ at tail. The area is characterized by arid climate. The mean annual rainfall is about $204 \mathrm{~mm}$. Mean monthly maximum and minimum temperature is $37.9^{\circ} \mathrm{C}$ and $22.9^{\circ} \mathrm{C}$ respectively. The average duration of sunshine per day is about 8.9 hours. The mean relative humidity is about $57 \%$.

*Corresponding author: Eshetu BD, Ethiopian Sugar Corporation, Research and Development Center, Wonji, Ethiopia, Tel: +251913243576; E-mail: Eshetu2011ec@gmail.com

Received September 21, 2018; Accepted November 23, 2018; Published November 30, 2018

Citation: Eshetu BD, Alamirew T (2018) Estimation of Seepage Loss in Irrigation Canals of Tendaho Sugar Estate, Ethiopia. Irrigat Drainage Sys Eng 7: 220. doi: 10.4172/2168-9768.1000220

Copyright: (c) 2018 Eshetu BD, et al. This is an open-access article distributed under the terms of the Creative Commons Attribution License, which permits unrestricted use, distribution, and reproduction in any medium, provided the original author and source are credited. 


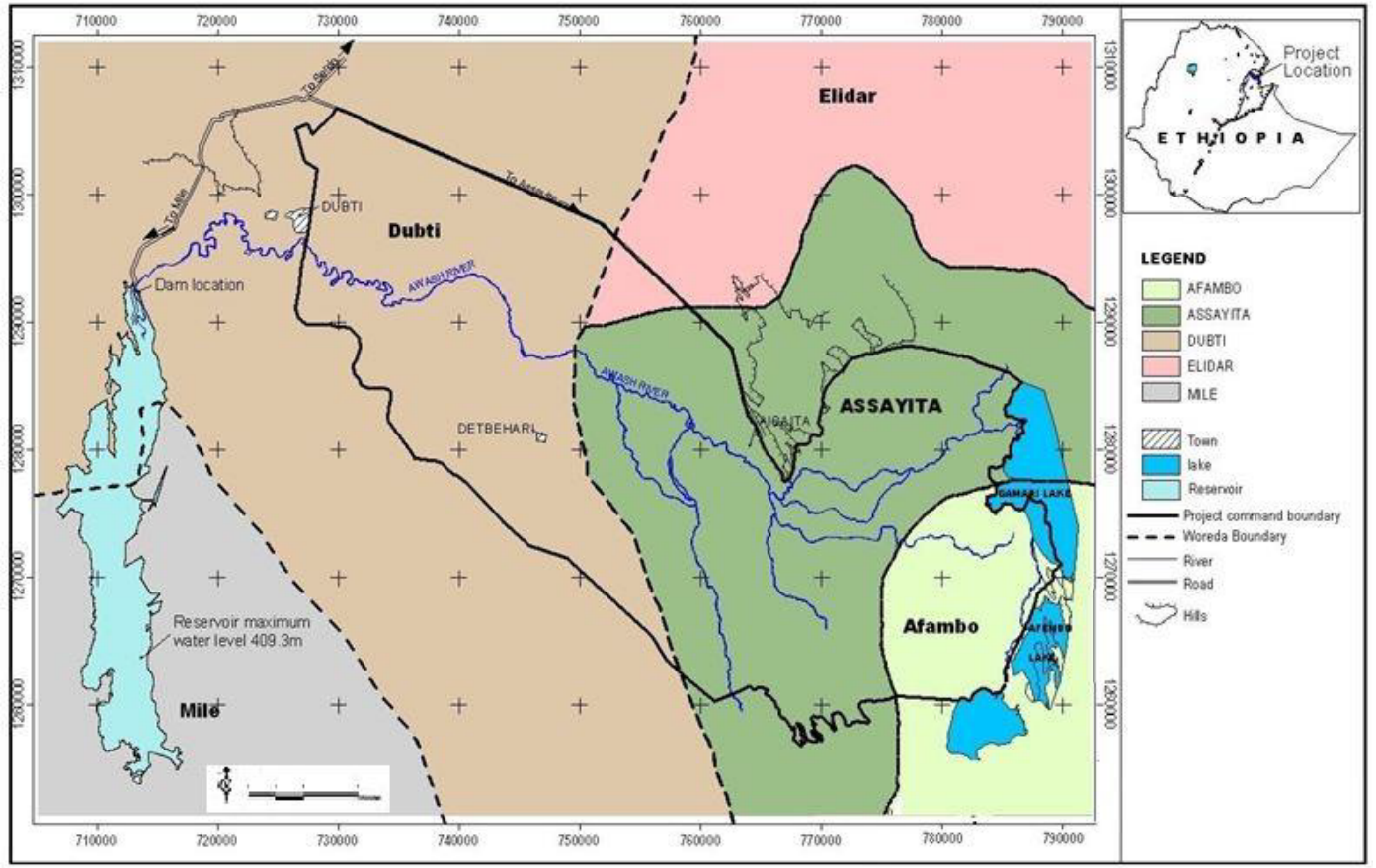

Figure 1: Tendaho irrigation project location map.

Soil of the Sugar Estate is classified into four major soil types (fluvisols, vertisols, solonetz and regosols) of which fluvisols and vertisols cover about 47 and $39 \%$ of the gross surveyed area respectively. In general, most of the soil are slightly to moderately alkaline with $\mathrm{PH}$ value ranging from 7.0 to 8.5 .

As per the design document of Tendaho Sugar Estate irrigation canals system, the layout consists of main canal and distribution system. The components of distribution system includes: Primary canal (Distributor), Secondary canal (Minor), Tertiary canal (Watercourse) and Quaternary canal (Field channel). The cross sections of all existing canal types are trapezoidal with side slope of $1.5 \mathrm{H}: 1 \mathrm{~V}$, bed slope of 0.0005 and Manning's roughness coefficient of 0.025 .

\section{Determination of canal seepage loss}

In this study, inflow-outflow method was used to measure seepage loss rate between two sections of selected canals. This method was used due to it is the most universally accepted method of seepage estimation in the open canals; It is advantageous being performed without intervening the operation of canals, and at the same time allowed sufficiently accurate measurements. Mostly, three canal segments at head, middle and tail end of canal reaches were selected, and the average seepage loss for the canal segments was determined. The length of canal segment was measured using a tape meter. With this method, the following eqn. (1) was used to calculate water seepage loss in defined canal sections of sufficient length $[7,8]$.

$$
Q_{s}=Q_{i}-Q_{o}-Q_{e}-D+I
$$

Where $Q_{s}$ is seepage loss in the canal segment (lit/s), $Q_{i}$ is inflow to the segment (lit/s), $Q$ is outflow from the segment (lit/s), $Q_{e}$ is evaporation (lit/s), $I$ is inflow to the segment from other sources (lit/s), and $D$ is water diverted from the segment (lit/s).

Seepage loss in the canals was calculated in three different ways: i) seepage loss per unit of canal length (lit/s/100 m), ii) seepage loss as a percentage of inflow $(\% / 100 \mathrm{~m})$, and iii) seepage loss per unit of wet area of the trapezoid canals per unit of time $\left(\mathrm{lit} / \mathrm{s} / \mathrm{m}^{2}\right)$.

To collect inflow/out $\left(\mathrm{Q}_{\mathrm{in} / \mathrm{out}}\right)$ discharge data without obstructing the operations, Valeport current meter model BFM001/002 was used and the average velocity of the flow was automatically calculated and displayed on display unit of the current meter. The velocities of flow were measured at 0.2 and 0.8 of full depths from surface of water for canals greater than $45 \mathrm{~cm}$ deep and at 0.6 full depth for shallow $(<45$ cm depth) canals.

Flows at the beginning and end of segments of the primary, secondary, and tertiary canals was calculated according to the velocityarea flow measurement method. The canal cross-section at the measurement points was first divided into 15 to $50 \mathrm{~cm}$ subsections based on the size of canal. At the same time, water depths of each subsection were measured, and cross sectional areas of each subsection were determined (Figures 2 and 3). The discharge was determined from the sum of the product of the mean velocity, depth and width between verticals using velocity-area method by the following equation (2) [9].

$$
q_{n}=\bar{v}_{n} d_{n} \frac{\left(b_{n+1}\right)-\left(b_{n-1}\right)}{2}
$$

where: $q_{n}$ is discharge through $n$ subsection, $\bar{v}_{n}$ is mean velocity, $d_{n}$ is depth of subsection and $b$ is width between verticals.

The total inflow or outflow discharge $\left(Q_{i / 0}\right)$ at a given cross section of the canal was calculated by the following eqn. (3)

$$
Q_{i / o}=\sum_{i=1}^{n} q_{n}
$$

During the measurement of inflow and outflow; normal operating condition of the canal, no change in water level during measurement, no water flow either from outside into the segment or from the segment to the outside (i.e., $D=0$ and $I=0$ ), nothing to prevent the flow, and 


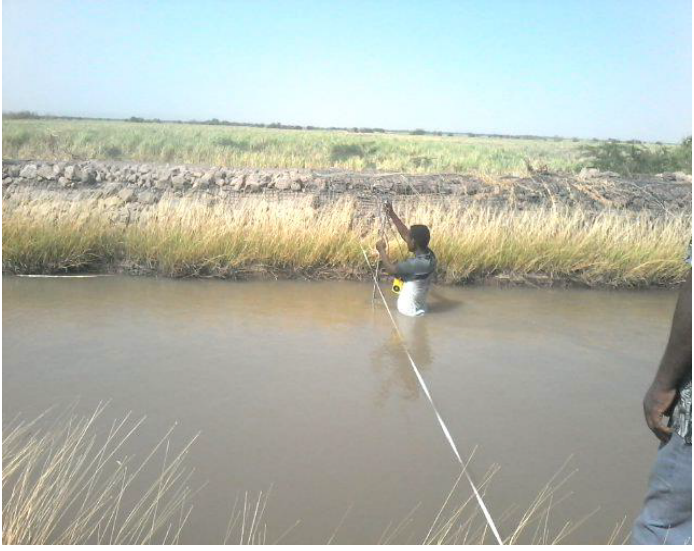

(a)

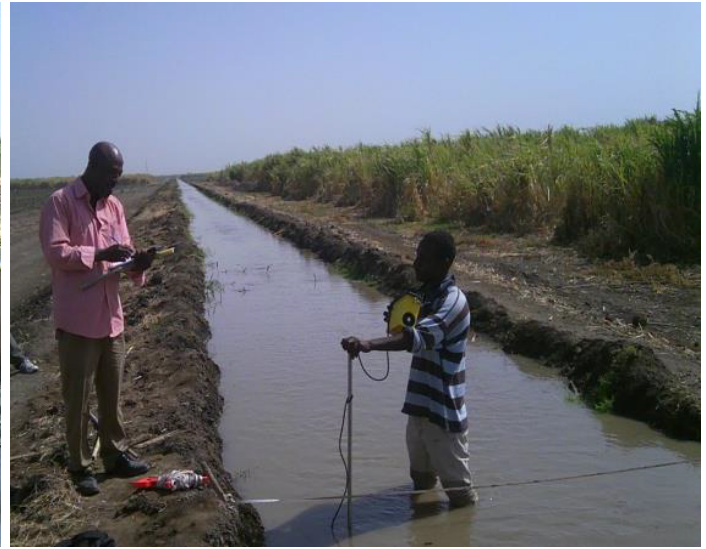

(b)

Figure 2: Cross section and velocity measurement of typical monitored primary canal 2 (a) and tertiary canal 611 (b).

Distance from edge of left bank (m)

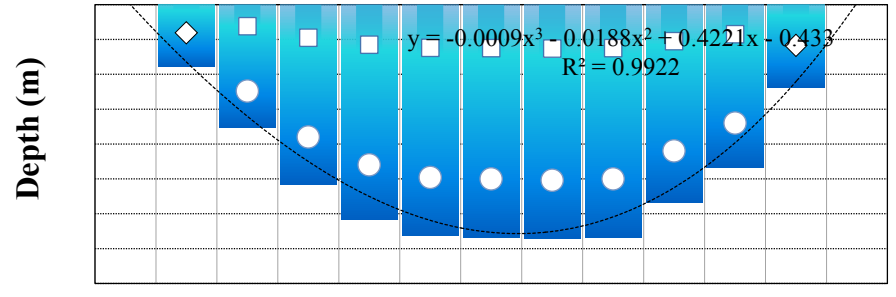

(a)

Distance from left bank edge (m)

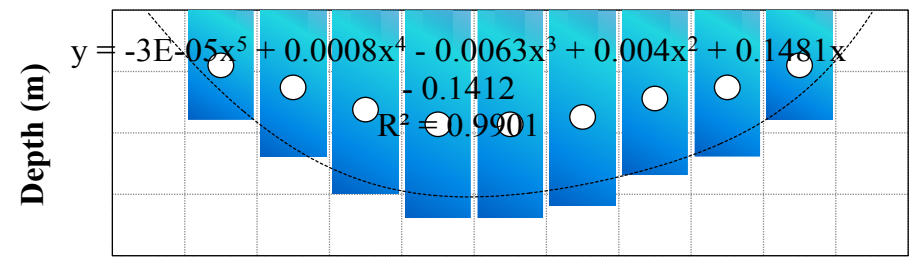

(b) depth (m)

depth at $20 \%$

(m)

- depth at $80 \%$

(m)

Figure 3: Cross section and velocity measurement depth of typical monitored primary canal4 (a) and tertiary canal 274 (b).

sufficient length of segment for measurement of conveyance loss were critically considered.

\section{Results and Discussion}

\section{Condition of monitored irrigation canals}

Classifying shapes of the canals in the sugar estate as trapizoidal is very difficult due to the fact that it has lost their original shapes as result of poor maintenance and repeated silt removing. The cross section of the canals were varied even within short distances, however, few canals exists with uniform shapes. Most of unlined canal sides and beds are covered with weeds, and the geo-mebrane lining is damaged.

Cross sectional area and velocity measurement depth (marked with white) of typical monitored primary canal 4 and tertiary canal 27 are shown in Figure 3a and 3b, respectively. From the Figures it can be seen that the shapes of the canals are parabolic, which are different from the design documents. This is probably due to changing the shape of the canals from trapezoidal to parabolic which is expected especialy in poorly maintained and repaired canals of the Sugar estate.

The total inflow and outflow discharge at a given cross section of the canal are presented in Tables 1-3. The smallest measured depth of the canal was $0.26 \mathrm{~m}$ in TC611 (Table 3) while the biggest was $1.02 \mathrm{~m}$ in PC4 (Table 1). The smallest measuerd canal widths was 1.43 in TC132 (Table 3) while the biggest was $7.0 \mathrm{~m}$ in PC4 (Table 1). The smallest discharge being measured was $58 \mathrm{lit} / \mathrm{sec}$ on TC116 (Table 3) while the biggest was $1375 \mathrm{lit} / \mathrm{sec}$ on the PC4 (Table 1).

\section{Seepage losses in irrigation canal}

In primary canals, the seepage losses of geo-membrane lined primary canals ( $\mathrm{PC} 1$ and $\mathrm{PC} 2$ ) and unlined primary canal- 4 result was 


\begin{tabular}{|c|c|c|c|c|c|c|c|c|c|}
\hline \multirow[t]{2}{*}{ Canal name } & \multirow[t]{2}{*}{ Length (m) } & \multirow[t]{2}{*}{ Depth (m) } & \multirow[t]{2}{*}{ Width (m) } & \multirow[t]{2}{*}{ Wetted per (m) } & \multirow[t]{2}{*}{ Inflow $\left(\mathrm{m}^{3} / \mathrm{s}\right)$} & \multirow[t]{2}{*}{ Outflow $\left(\mathrm{m}^{3} / \mathrm{s}\right)$} & \multicolumn{3}{|c|}{ Seepage losses } \\
\hline & & & & & & & Lit/s/100 m & $\% / 100 \mathrm{~m}$ & Lit/s/ m² \\
\hline PC1 & 1500 & 0.86 & 4.50 & 3.98 & 0.8277 & 0.7507 & 5.13 & 0.64 & 0.0129 \\
\hline PC2 & 933 & 1.00 & 4.48 & 3.88 & 1.0400 & 0.9953 & 4.79 & 0.46 & 0.0123 \\
\hline \multicolumn{7}{|c|}{ Average of lined canal } & 4.94 & 0.55 & 0.0126 \\
\hline PC4 & 375 & 1.02 & 7.00 & 6.39 & 1.3750 & 1.3320 & 11.47 & 0.84 & 0.0180 \\
\hline
\end{tabular}

PC: Primary Canal

Table 1: Seepage water loss in the primary irrigation canal.

\begin{tabular}{|c|c|c|c|c|c|c|c|c|c|}
\hline \multirow[t]{2}{*}{ Canal name } & \multirow[t]{2}{*}{ Length (m) } & \multirow[t]{2}{*}{ Depth (m) } & \multirow[t]{2}{*}{ Width ( m) } & \multirow[t]{2}{*}{ Wetted per (m) } & \multirow[t]{2}{*}{ Inflow $\left(\mathrm{m}^{3} / \mathrm{s}\right)$} & \multirow[t]{2}{*}{ Outflow $\left(\mathrm{m}^{3} / \mathrm{s}\right)$} & \multicolumn{3}{|c|}{ Seepage losses } \\
\hline & & & & & & & Lit/s/100 m & $\% / 100 \mathrm{~m}$ & Lit/s/m ${ }^{2}$ \\
\hline SC11 & 200 & 0.63 & 1.66 & 1.28 & 0.2350 & 0.2200 & 7.50 & 3.38 & 0.0635 \\
\hline SC13 & 267 & 0.44 & 1.65 & 1.39 & 0.2083 & 0.1830 & 9.48 & 5.56 & 0.0689 \\
\hline SC22 & 300 & 0.38 & 2.43 & 2.20 & 0.1560 & 0.1337 & 7.44 & 4.99 & 0.0339 \\
\hline SC211 & 800 & 0.44 & 2.50 & 2.23 & 0.2227 & 0.1803 & 5.10 & 2.27 & 0.0227 \\
\hline SC42 & 233 & 0.63 & 2.80 & 2.42 & 0.3170 & 0.3020 & 6.24 & 2.35 & 0.0258 \\
\hline SC62 & 200 & 0.46 & 3.25 & 2.97 & 0.1960 & 0.1843 & 5.83 & 3.33 & 0.0198 \\
\hline \multicolumn{7}{|c|}{ Average } & 6.93 & 3.65 & 0.0391 \\
\hline
\end{tabular}

SC: Secondary, Per: Perimeter

Table 2: Water loss in the secondary irrigation canals.

\begin{tabular}{|c|c|c|c|c|c|c|c|c|c|}
\hline \multirow[t]{2}{*}{ Canal name } & \multirow[t]{2}{*}{ Length (m) } & \multirow[t]{2}{*}{ Depth (m) } & \multirow[t]{2}{*}{ Width ( m) } & \multirow[t]{2}{*}{ Wetted per (m) } & \multirow[t]{2}{*}{ Inflow $\left(\mathrm{m}^{3} / \mathrm{s}\right)$} & \multirow[t]{2}{*}{ Outflow $\left(\mathrm{m}^{3} / \mathrm{s}\right)$} & \multicolumn{3}{|c|}{ Seepage losses } \\
\hline & & & & & & & Lit/s/100 m & $\% / 100 \mathrm{~m}$ & Lit $/ \mathbf{s} / \mathbf{m}^{2}$ \\
\hline TC111 & 190 & 0.38 & 1.72 & 1.49 & 0.1333 & 0.1250 & 4.37 & 3.28 & 0.0297 \\
\hline TC114 & 233 & 0.31 & 1.55 & 1.36 & 0.0987 & 0.0887 & 4.263 & 4.34 & 0.0314 \\
\hline TC116 & 250 & 0.31 & 1.85 & 1.67 & 0.0675 & 0.0580 & 3.795 & 5.65 & 0.0228 \\
\hline TC132 & 217 & 0.32 & 1.43 & 1.24 & 0.0870 & 0.0783 & 4.030 & 4.61 & 0.0326 \\
\hline TC133 & 207 & 0.32 & 1.70 & 1.51 & 0.0877 & 0.0797 & 3.854 & 4.42 & 0.0255 \\
\hline TC221 & 175 & 0.38 & 2.00 & 1.77 & 0.1280 & 0.1190 & 5.246 & 4.08 & 0.0296 \\
\hline TC223 & 183 & 0.27 & 1.85 & 1.69 & 0.0900 & 0.0833 & 3.718 & 4.17 & 0.0221 \\
\hline TC271 & 200 & 0.29 & 1.90 & 1.72 & 0.0885 & 0.0785 & 4.998 & 5.59 & 0.0288 \\
\hline TC423 & 333 & 0.35 & 2.40 & 2.19 & 0.1300 & 0.1197 & 3.048 & 2.35 & 0.0139 \\
\hline TC427 & 200 & 0.35 & 1.88 & 1.67 & 0.0825 & 0.0750 & 3.743 & 4.50 & 0.0225 \\
\hline TC611 & 200 & 0.26 & 1.93 & 1.77 & 0.0970 & 0.0900 & 3.493 & 3.61 & 0.0198 \\
\hline TC625 & 350 & 0.27 & 2.25 & 2.09 & 0.0760 & 0.0625 & 3.866 & 5.11 & 0.0189 \\
\hline \multicolumn{7}{|c|}{ Average } & 3.933 & 4.27 & 0.0248 \\
\hline
\end{tabular}

TC: Tertiary Canal, Per: Perimeter

Table 3: Seepage water loss in the tertiary irrigation canals.

stated in Table 1 . From the result, the lowest seepage loss was $0.46 \%$ per $100 \mathrm{~m}\left(0.0123 \mathrm{lit} / \mathrm{s} / \mathrm{m}^{2}\right)$ in the lined primary canal -2 and the highest seepage loss was $0.84 \%$ per $100 \mathrm{~m}\left(0.0180 \mathrm{lit} / \mathrm{s} / \mathrm{m}^{2}\right)$ in unlined primary canal- 4 . The average seepage loss in the unlined was higher than the lined primary canal by $0.29 \%$ per $100 \mathrm{~m}$ of canal length $(0.054 \mathrm{lit} / \mathrm{s} /$ $\mathrm{m}^{2}$ wetted area of canal). In secondary canals, the seepage loss result is presented in Table 2. From the result, the lowest seepage loss was $2.27 \%$ per $100 \mathrm{~m}\left(0.0227 \mathrm{lit} / \mathrm{s} / \mathrm{m}^{2}\right)$ in the secondary canal 211 and the highest was $5.56 \%$ per $100 \mathrm{~m}\left(0.0689 \mathrm{lit} / \mathrm{s} / \mathrm{m}^{2}\right)$ in the secondary canal 13 . The average was $3.65 \%$ per $100 \mathrm{~m}$ of canal length $\left(0.0391 \mathrm{lit} / \mathrm{s} / \mathrm{m}^{2}\right)$. In the tertiary canal, the seepage loss result is presented in Table 3 . From the result, the lowest seepage loss was $2.35 \%$ per $100 \mathrm{~m}\left(0.0139 \mathrm{lit} / \mathrm{s} / \mathrm{m}^{2}\right)$ in the tertiary canal 423 and the highest was $5.65 \%$ per $100 \mathrm{~m}(0.0228$ lit $\left./ \mathrm{s} / \mathrm{m}^{2}\right)$ in the tertiary canal 116 , with an average of $4.27 \%$ per $100 \mathrm{~m}$ of canal length (0.0248 lit $/ \mathrm{s} / \mathrm{m}^{2}$ of wetted area of canals).

The average seepage losses found in this study are comparable to other results found in various lined and unlined irrigation canals. The previous study conducted on unlined canals at Wonji-Showa Sugar Estate showed that mean seepage losses was $0.00243 \mathrm{lit} / \mathrm{s} / \mathrm{m}^{2}$ [5]. Similarly, an average seepage loss of $0.0141 \mathrm{lit} / \mathrm{s} / \mathrm{m}^{2}$ was also found in lined canal in Turkey [7]. In addition, an average seepage loss of 0.00893 lit $/ \mathrm{s} / \mathrm{m}^{2}$ was also found in lined canal in Pakistan[10]. However, the average seepage loss obtained for lined primary canals in this study was much higher than the standard of seepage for lined canals. For lined canals standard of seepage loss is about $0.00024 \mathrm{lit} / \mathrm{s}$ per $\mathrm{m}^{2}$ [11]. The seepage losses found in this study for unlined canals were also much higher than the recommended for unlined canals of clay soils. For canals of clay soil, the standard seepage and expected seepage losses are within the ranges of $0.00093 \mathrm{lit} / \mathrm{s} / \mathrm{m}^{2}$ to $0.0013 \mathrm{lit} / \mathrm{s} / \mathrm{m}^{2}$ [11].

The excess of seepage loss found in this study may be attributed to the damage and removal of the geo-membrane of primary canals and high plant growth, deformed canal shape, and deterioration of water sealing material for unlined primary, secondary and tertiary canals $[5,6]$. The maintenance conditions during the flow measurement were found to be very poor. This shows that maintenance and repairs have to be performed on the canals.

\section{Conclusion and Recommendation}

\section{Conclusion}

Seepage loss for lined and unlined irrigation canals that convey and distribute water, and also cross sectional area of canal in Tendaho 
Citation: Eshetu BD, Alamirew T (2018) Estimation of Seepage Loss in Irrigation Canals of Tendaho Sugar Estate, Ethiopia. Irrigat Drainage Sys Eng 7: 220. doi: 10.4172/2168-9768.1000220

Sugar Estate was measured. Based on the result of the study, the average values of seepage loss in the canals were $0.55 \%$ per $100 \mathrm{~m}(0.0126$ lit $\left./ \mathrm{s} / \mathrm{m}^{2}\right)$ and $0.84 \%$ per $100 \mathrm{~m}\left(0.0180 \mathrm{lit} / \mathrm{s} / \mathrm{m}^{2}\right)$ for lined and unlined primary canals respectively, and $3.65 \%$ per $100 \mathrm{~m}\left(0.0391 \mathrm{lit} / \mathrm{s} / \mathrm{m}^{2}\right)$ and $4.27 \%$ per $100 \mathrm{~m}\left(0.0248 \mathrm{lit} / \mathrm{s} / \mathrm{m}^{2}\right)$ for secondary and tertiary canals, respectively. Moreover, the seepage loss in unlined primary canal was higher than the lined primary canal by $0.29 \%$ per $100 \mathrm{~m}$ of canal length $\left(0.054 \mathrm{lit} / \mathrm{s} / \mathrm{m}^{2}\right)$. It can be concluded that the average seepage loss was higher than the standard seepage value for both lined and unlined canal types besides the shapes of most of canals cross sections are changed.

\section{Recommendation}

In order to reduce excess seepage loss, there should be regular maintenance and repair program for irrigation canals of the Estate. Making sure that the people will not also damage the canals and the structures when they get water for their animals and other uses. Canal linings that are more economical, effective, durable, and long lasting should be used; the feasibility of new economic measures to reduce water conveyance loss in the network should be studied.

\section{References}

1. Ahuchaogu I, Imeh E, Anwana E (2015) Evaluation of seepage losses in an earth lined canal: A Case study of University of Uyo Farm, Uyo, Nigeria. IJESMR2: 2349-6193.
2. Arunkumar R, Ambujam NK (2010) Performance assessment of canal irrigation system. ISH J HYDRAUL ENG-ASCE 16: 146-155.

3. Uchdadiya KD, Patel JN (2014) Seepage losses through unlined and lined canals. Int J Adv Appl Math And Mech 2: 88-91.

4. Swamee PK, Mishra GC, Chahar BR (2002) Design of minimum water-loss canal sections. J HYDRAUL RES-ASCE 40: 215-220.

5. Kedir $Y$ (2015) Estimation of conveyance losses of Wonji-Shoa sugar cane irrigation scheme in Ethiopia. Environ Earth Sci 5: 2224-3216.

6. Shonka TG (2017) Performance Evaluation of Field Water Application at Tendaho Sugar Estate, Ethiopia. Irrigat Drainage Sys Eng 6: 199.

7. Akkuzu E, Nal HB, Karatafi B (2007) Determination of water conveyance loss in the Menemen Open Canal Irrigation Network. Turk J Agric For 31: 11-22.

8. ANCID (Australian National Committee on Irrigation and Drainage) (2003) Open Channel Seepage and Control Best Practice Guidelines for Channel Seepage Identification and Measurement.

9. MoE (Ministry of Environment) (1998) Manual of Standard Operation Procedures for Hydrometric Surveys in British Columbia.

10. Arshad M, Ahmad N, Usman M, Shabbir A (2009) Comparison of Water Losses Between Unlined and Lined Watercourses in Indus Basin Of Pakistan. Pak Agri Sci 46: 280-284.

11. USRB (US Bureau of Reclamation) (1976) Linings for Irrigation Canals, Bureau of Reclamation, United States Department of the Interior, Washington DC, USA. 